\title{
Socio-demographic Characteristics of Women having Vaginal Discharge attending a Military Hospital
}

\author{
Yasmin $\mathrm{S}^{1}$, Zaman $\mathrm{NA}^{2}$, Zafreen $\mathrm{F}^{3}$ \\ DOI: https://doi.org/10.3329/jafmc.v14i2.45905
}

\begin{abstract}
Abstruct
Introduction: Vaginal discharge is the commonest concern among women and leads many women to visit Gynaecology OPD. It is a normal part of women reproductive cycle, unless it causes itching, burning or other bothersome symptoms. Association between vaginal discharge and reproductive tract is weak. Psychological factors also contribute in vaginal discharge. So the problem of vaginal discharge can be best understood not only in bio-medical perspective but also in socio-cultural perspective. Proper understanding of the subject is required for appropriate medical intervention and bringing awareness among women.
\end{abstract}

Objectives: To determine prevalence of vaginal discharge, the socio-demographic factors associated with it, women's perceptions of vaginal discharge and their treatment seeking behaviour.

Materials and Methods: This cross sectional study was performed at outpatients' Department of Obstetrics and Gynecology, Combined Military Hospital, Chattogram from January 2016 to January 2017. Total 150 women with complains of vaginal discharge were interviewed with questionnaire.

Results: Most of the patients63(42\%) belong to 25-34 age group, $86(57.3 \%)$ had poor sanitation facilities and $126(84 \%)$ used cloth pads during menstrual period. Many of them had backache $64(42.6 \%)$ followed by itching, bad smell $48(32 \%)$ and lower abdominal pain $15(10 \%)$. Most of the cases 98(65.3\%) were multiparous.

Conclusion: To diminish the problem of vaginal discharge women should improve their health knowledge, empower economic status, maintain personal hygiene. Further study is needed for better outcome.

Key-words: Vaginal discharge, Poor sanitation, Reproductive age.

\section{Introduction}

Vaginal discharge is the commonest reproductive tract infection among women. One fourth of the women of gynaecology outpatient department (OPD) has the complaints of vaginal discharge ${ }^{1}$. Vaginal discharge serves a significant house-keeping function in the female reproductive system.
Fluid made by glands inside the vagina and cervix carries away dead cells and bacteria. This retains the vagina clean and helps prevent infection. Most of the time vaginal discharge is perfectly regular. The amount can differ, as can odor and color depending on the time of menstrual cycle.Though in rural Bangladesh vaginal discharge is commonly known as 'swedpradhar' but the medical persons used to describe this as 'leucorrhea'2. Secretions from endometrial glands, cervical glands and vagina contribute to this discharge. This may be physiological or pathological. Increase in normal vaginal secretions progresses physiologically at puberty, during pregnancy, at ovulation, sexual arousal and premenstrual phase of menstrual cycle. Pathological vaginal discharges may be infectious or non-infectious ${ }^{1,3}$. Infectious discharge may be due to specific infections such as Gonorrhoea, Trichomoniasis, Chlamydiasis which are sexually transmitted and disturbances in the normal vaginal flora cause Moniliasis and Bacterial vaginosis. Some amount of vaginal discharge is perceived by many women as normal. Women resort to medical help when it is excessive or they have fear of contracting a sexually transmitted infection or cancer ${ }^{4}$.

Studies from Bangladesh and India have shown that only 30 to 60 percent of women with vaginal discharge had laboratory evidence of infection ${ }^{5,6}$. In the remaining cases no infectious cause was detected. Strong association between psychological adversity and vaginal discharge has been observed in South Asian women ${ }^{7}$. Another study done in North India has shown that women who experienced domestic violence had greater odds of reporting symptoms of gynaecological morbidity ${ }^{8}$. Genital secretions are thought to be a highly purified form of bodily substance and loss of this precious substance is thought to result in progressive weakness and even death. In this study the main objective is to evaluate the prevalence and socio-demographic correlates of vaginal discharge among married women of reproductive age group in Combined Military Hospital (CMH).

\section{Materials and Methods}

This cross sectional study was conducted at Obstetrics and Gynaecology OPD of CMH, Chattogram from January 2016 to January 2017. During the study 150 women with complains of

1. Lt Col Shamima Yasmin, MBBS, DGO, FCPS, Classified Specialist in Gynaecology and Obstetrics, CMH, Chattogram (E-mail: yasminshamima1047@gmail.com) 2. Brig Gen Nasrin Ara Zaman, MBBS, DGO, FCPS, Adviser Specialist in Gynaecology and Obstetrics, CMH, Jashore 3. Dr Farzana Zafreen, MBBS, MPH, Associate Professor and Head, Department of Community Medicine, Medical College for Women \& hospital, Uttara, Dhaka. 
vaginal discharge were interviewed with questionnaire; sociodemographic details, details of obstetric history, contraceptive practices, personal and menstrual hygiene were noted. Statistical analysis was performed by SPSS 12.0 for Windows. The proportions and frequency tables were used to summarize categorical variables.

\section{Results}

Among 150 respondents' most of the patients $63(42 \%)$ belong to age group 25-34 followed by age group 35-44 having $51(34 \%)$ patients. Most of the patients $98(65.3 \%)$ completed primary and secondary level education and $68(45.3 \%)$ were housewives. Most of the patients $100(66.7 \%)$ belong to lower and lower middle economic class. Patients' husbands completed primary and secondary level education were 79(52.7\%). About 126(84\%) patients use cloth pads and $86(57.3 \%)$ had poor sanitation facilities (Table-I). Majority of the patients $87(58 \%)$ were married before 18 years of age, most of the patients $119(79.3 \%)$ were multi-para and $106(70.7 \%)$ had history of institutional delivery (Table-II). Table-III showed distribution of the respondents based on morbidity associated with discharge where most of the respondents had general weakness $115(76.5 \%)$ regarding gynecological symptoms about $64(42.7 \%)$ present with backache followed by itching and bad smell $48(32 \%)$ and lower abdominal pain $15(10 \%)$.

Table-l: Distribution of patients by socio-demographic characteristics $(n=150)$

\begin{tabular}{|c|c|c|c|}
\hline Characteristics & Demographic factors & Frequency & Percentage \\
\hline \multirow{4}{*}{ Age in years } & $15-24$ & 28 & 18.7 \\
\hline & $25-34$ & 63 & 42.0 \\
\hline & $35-44$ & 51 & 34.0 \\
\hline & $45-54$ & 7 & 5.3 \\
\hline \multirow{2}{*}{ Education } & Primary and secondary school & 98 & 65.3 \\
\hline & Higher secondary and above & 52 & 34.7 \\
\hline \multirow{3}{*}{ Occupation } & Housewife & 68 & 45.3 \\
\hline & Teacher & 23 & 15.3 \\
\hline & Social skilled worker & 59 & 39.4 \\
\hline \multirow{4}{*}{$\begin{array}{l}\text { Economic } \\
\text { status }\end{array}$} & Upper class & 20 & 13.3 \\
\hline & Middle class & 30 & 20.0 \\
\hline & Lower middle class & 40 & 26.7 \\
\hline & Lower class & 60 & 40.0 \\
\hline \multirow{2}{*}{$\begin{array}{l}\text { Husband's } \\
\text { Education status }\end{array}$} & Primary and secondary school & 79 & 52.7 \\
\hline & Higher secondary and above & 71 & 47.3 \\
\hline \multirow{3}{*}{ Use of pad } & Sanitary pads & 21 & 14.0 \\
\hline & Cloth pads & 126 & 84.0 \\
\hline & Both & 3 & 2.0 \\
\hline \multirow{2}{*}{ Types of toilet } & Poor sanitation facilities & 86 & 57.3 \\
\hline & Good sanitation facilities & 64 & 42.7 \\
\hline \multirow{2}{*}{ Types of family } & Joint & 18 & 12.0 \\
\hline & Nuclear & 132 & 88.0 \\
\hline
\end{tabular}

\begin{tabular}{|c|c|c|c|c|}
\hline \multicolumn{3}{|c|}{ Obstetric history } & Frequency & Percentage \\
\hline \multirow{2}{*}{ Marital age } & \multicolumn{2}{|c|}{ Less than 18 years } & 87 & 58.0 \\
\hline & \multicolumn{2}{|c|}{ More than 18 years } & 63 & 42.0 \\
\hline \multirow{3}{*}{$\begin{array}{l}\text { History } \\
\text { abortions }\end{array}$} & \multirow{2}{*}{ Yes } & Induced abortion & 6 & 4.0 \\
\hline & & Spontaneous & 13 & 8.7 \\
\hline & No & & 131 & 87.3 \\
\hline \multirow{4}{*}{ Parity } & \multicolumn{2}{|c|}{ Nulliparous } & 16 & 10.7 \\
\hline & \multicolumn{2}{|c|}{ Para 1} & 15 & 10.0 \\
\hline & \multicolumn{2}{|c|}{ Para 2} & 21 & 14.0 \\
\hline & \multicolumn{2}{|c|}{ Para > 2} & 98 & 65.3 \\
\hline \multirow{4}{*}{ Place of delivery } & \multicolumn{2}{|c|}{ Home } & 20 & 13.3 \\
\hline & \multicolumn{2}{|c|}{ Institutional } & 106 & 70.7 \\
\hline & \multicolumn{2}{|c|}{ Both } & 8 & 5.3 \\
\hline & \multicolumn{2}{|c|}{\begin{tabular}{|l|}
$\mathrm{Nil}$ \\
\end{tabular}} & 16 & 10.7 \\
\hline
\end{tabular}

Table-III: Distribution of patients by symptoms $(n=150)$

\begin{tabular}{|l|l|r|r|}
\hline Characteristics & Demographic factors & Frequency & Percentage \\
\hline \multirow{4}{*}{$\begin{array}{l}\text { General } \\
\text { Symptoms }\end{array}$} & General weakness & 115 & 76.7 \\
\cline { 2 - 4 } & Leg cramp & 6 & 4.1 \\
\cline { 2 - 4 } & Body ache & 9 & 5.9 \\
\cline { 2 - 4 } & Urinary problem & 2 & 1.3 \\
\cline { 2 - 4 } & Abdominal pain & 5 & 3.3 \\
\cline { 2 - 4 } & Weight loss & 2 & 1.3 \\
\cline { 2 - 4 } & Anaemia & 6 & 4.1 \\
\cline { 2 - 4 } & Nothing & 5 & 3.3 \\
\hline \multirow{4}{*}{$\begin{array}{l}\text { Gynecological } \\
\text { Symptoms }\end{array}$} & Dysuria & 8 & 5.3 \\
\cline { 2 - 4 } & Menstrual disorders & 14 & 9.3 \\
\cline { 2 - 4 } & Itching \& bad smell & 48 & 32.0 \\
\cline { 2 - 4 } & Lower abdominal pain & 16 & 10.7 \\
\cline { 2 - 4 } & Backache & 64 & 42.7 \\
\hline
\end{tabular}

\section{Discussion}

In this study, was found high prevalence of vaginal discharge in age group 25-34 years old women. Whereas in many studies found prevalence rate is higher in younger age group of $15-24$ years ${ }^{7,9}$. It may possibly be due to younger age at marriage, the immature cervical epithelium is more susceptible to the ascending infections, lack of use of contraceptive methods, early child bearing and obstetric morbidity related to it. However another study reported a higher prevalence rate among married women who were more than 40 years of age ${ }^{6}$. The vaginal discharge was found more in widows and divorced women than women living with spouse in some studies. This is probably due to depression and psychological distress which is described as medically unexplained component of white discharge ${ }^{10}$. In the study, it was found that there is decreased prevalence of vaginal discharge with increasing educational status of women. A similar trend was observed by other studies ${ }^{9,10}$. During the study, it was noticed that vaginal discharge was found to be more prevalent in women belonging to lower class and lower middle class. These findings are compatible with other studies ${ }^{11}$. Poor personal and genital hygiene may be responsible for this. We also found that women whose spouses were educated up to high school and above had lesser prevalence of vaginal discharge. There is 
evidence of association between vaginal discharge and history of habits of husbands like drinking and sexual promiscuity. This is similar to other articles ${ }^{7,9}$.

The age at marriage of women was strongly associated with vaginal discharge. Women married at less than 18 years of age had a greater prevalence of vaginal discharge. Early onset of sexual activities may predispose the immature cervical epithelium to ascending infections. In this study, we found an increase in prevalence of vaginal discharge with increasing parity, this is also similar to other reports ${ }^{9}$. During the study we observed a strong association between vaginal discharge and usage of toilet. Prevalence is more in the respondents who had no toilet facility at home (open air defecation). This is also in consonance with other findings 9 . This may be due to improper cleaning of perineum following urination and defecation or due to non-availability of adequate amount of water for cleaning. In our study we also noted that reproductive tract infections were higher among women who used cloth of homemade pads which was similar to other reports ${ }^{9}$.

\section{Conclusion}

Patients with low socio-economic condition and less education status found high prevalence of vaginal discharge. We can conclude that improvement of health knowledge, economic status, maintenance of personal health and women's empowerment will help to mitigate the problem of vaginal discharge.

\section{References}

1. Koenig M, Jejeebhoy S, Singh S. Investigating women's gynaecological morbidity in India: not just another KAP survey. Reprod Health Matters 1998; 6:1-13.

2. Dutta DC. Abnormal vaginal discharge, HiralalKonar Ed, DC Dutta's text book of Gynecology, 7th ed. Jaypee Brothers medical publishers (P) Ltd, New Delhi, India; 2013:551-5.
3. Selvarani G. An international program for reproductive tract infections among women in a selected area in rural Tamil Nadu, India. South East Asian Studies Manual 2000; 2000:121-3.

4. Indira Guntoory et al. Prevalence and Socio-demographic correlates of Vaginal Discharge among married women of reproductive age at a teaching hospital. IJRCOG 2017; 6(11):4840-6.

5. Vishwanath S, Talwar V, Prasad Ret al. Syndromic management of vaginal discharge among women in a reproductive health clinic in India. Sex TransmInfec 2007; 76(4):303-6.

6. Hawkes S, Morison L, Foster S et al. Reproductive tract infection in women in low income, low prevalence situations: assessment of syndromic management in Matlab, Bangladesh. Lancet 1999; 354:1776-81.

7. Patel V, Pednekar S, Weiss $\mathrm{H}$ et al. Why do women complain of vaginal discharge? A population survey of infectious and psychological risk factors in a South Asian community. Int J Epidemiol 2005; 34(4):853-62.

8. Rob S, Michael AK, Saifuddin A. Domestic violence and symptoms of Gynaecological morbidity among women in North India. International Family Planning Perspective 2006; 32(4):201-8.

9. Mani G. Prevalence of reproductive tract infections among rural married women in Tamil Nadu, India: A community based study. J Pioneer Med Sci 2014; 4(1):18-24.

10. Patel V, Oomman N. Mental health matters too: Gynecological symptoms and depression in South Asia, Reproductive Health Matters 1999; 7(14):30-38.

11. Kulkarni RN, Durge PM. A study of leucorrhoea in reproductive age group women of Nagpur city. Indian J Public Health 2005; 49(4):238-9. 